\title{
Leadership as a Determinant of EFQM Excellence: Model Implementation in Slovenian Higher Education Institutions
}

\section{Maja Pungeršek}

University of Primorska, Slovenia maja.pungersek@gmail.com

Matjaž Maletič

University of Maribor, Slovenia

matjaz.maletic@um.si

\author{
Damjan Maletič \\ University of Maribor, Slovenia \\ damjan.maletic@um.si \\ Maja Meško \\ University of Primorska, Slovenia \\ maja.mesko@fm-kp.si
}

One major means to address stakeholder pressures concerning the improvement of the higher education services is the use of Business Excellence Models (B EMS) which attracted attention of both academics and practitioners. In particular, this study aims to assess the applying of the leadership criterion in the higher education institutions according to European Foundation for Quality Management (E FQM) Excellence Model. The study draws upon Common Assessment Framework (CAF) 2013 and EFQM 2013 model as references to measure the key leadership dimensions. Using empirical data based on a large-scale survey among employees within Slovenian higher education institutions (HEIS) this paper utilized the Partial Least Squares Path Modeling (PLS-PM) in order to investigate the relationships between leadership dimensions and influential factors regarding the adoption of the EFQM model in HEIS. The results showed that two leadership dimensions directly influence the implementation enablers (i.e. the perception of the employees regarding the influence of the leadership dimensions on the EFQM Excellence Model implementation), while other dimension indirectly influence the implementation enablers. The main conclusion is that a greater engagement in leadership criterion serves as a driving force of the EFQM Excellence model adoption in HEIS. The paper contributes to an ongoing discussion of a need of excellence models being adapted in higher education institutions. Hence, by investigating the leadership criterion of the EFQM Excellence Model, this study reinforces previous findings highlighting the need to integrate quality management perspective within the frame of higher education sector.

Key Words: CAF, EFQM, higher education, leadership, excellence, PLS-PM JEL Classification: M12, I21, I23

https://doi.org/10.26493/1854-6935.18.45-66 


\section{Introduction}

Nowadays, higher education institutions (HEIS) face important challenges, such as the need of responding to diverse social demands, increase of educational spending as well as the need to adapt to the new age of information and knowledge (Calvo-Mora, Leal, and Roldan 2006). Stensaker (2007) states that the assurance of quality is becoming an important part of HEIs. According to Brennan and Shah (2000), the processes of establishing of quality assurance influences the balance of powers inside the HEI as well as has an important impact on the manner of decisionmaking. A transparent way of accomplishing the whole process of quality should force the leaders of HEI to make rational decisions and support the latter with evidence. Murgatroyd and Morgan (1993) insist that no approach to quality can work if there are no completely engaged leaders, who enable the emergence of philosophy and quality culture. These leaders must develop three dimensions of management, which are trust, transferring the power onto the employees and involving of other stakeholders in management.

In last decades, different approaches have been adopted for the introduction of quality management in HEIs, such as self-assessment and external assessment of the institutions, accreditation and certification systems as well as different models of Total Quality Management - TQM (Wiklund et al. 2003). Accordingly, the spread of self-evaluation, considered as the essential requirement for continuous performance improvement and benchmarking, is supported by the adoption of quality models such as the European Foundation for Quality Management (EFQM) model and Common Assessment framework (CAF) thoroughly tested in the public and private sector (Cappelli et al. 2011). It could be argued that self-assessment and quality management systems are important in HEIS (Tarí 2006; Srikanthan and Dalrymple 2004). As argued by Tarí (2006) the development of leadership within HEI is important in any continuous improvement process.

Prior literature has extensively addressed the leadership from a wide array of perspectives. As pointed out by Rao Tummala and Tang (1996) leaders are responsible for creating clear and visible quality values and high expectations and for integrating them into the way the organization operates. This requires their strong personal commitment and involvement. Leaders must take part as role models in the creation of strategies, systems, and methods for achieving excellence in quality. Laksh- 
man (2006) highlighted that the role of leadership in managing quality is relatively unaddressed in the leadership literature. Several researchers in the quality management literature have pointed to the importance of the role of leadership in managing quality (e.g. Kaynak 2003; Sila 2007). There seems to be a strong consensus among the founders of the quality movement as far as the importance of leadership to managing quality is concerned (Dahlgaard Park 2011; Idris and Zairi 2006; Kanji 2008). The above arguments are supported by prior studies (e.g. Eskildsen and Dahlgaard 2000) which emphasise the positive association between leadership and the other key TQM implementation factors.

The importance of leadership has been discussed also in the context of the HEI environment. Prior studies (Osseo-Asare, Longbottom, and Murphy 2005; Calvo-Mora, Leal, and Roldan 2006) have highlighted that leadership is a key factor in the success of the EFQM implementation in higher education institutions. Furthermore, Flumerfelt and Banachowski (2011) identified several key leadership paradigms for improvement in higher education (e.g. allocating resources, clarifying roles and responsibilities, communication, planning etc.), especially those related to quality and business excellence models. It is argued that these paradigms eventually improve the quality of services in higher education.

The importance of leadership in Slovenian educational system, can also be confirmed in the work of Sentočnik (2012) who suggests that note that leadership of HEI represents a critical lever to create and maintain an efficient $\mathrm{HE}$, which encourages higher student achievements (Hallinger and Heck 1996; Leithwood et al. 2007). In recent years, dispersed leadership has achieved more attention, especially because of understanding leadership as a function that serves as interaction of all stakeholders of HEI (Spillane and Camburn 2006). The model of dispersed leadership represents powerful stress on the performance of HEI as a whole, and allows more focus on the relations between leaders of $\mathrm{HEI}$, as the preparation for managing and developing HEI shows the complexity of leading roles and a rise in pressure and responsibility.

Although there are an increasing number of higher education institutions (HEIs) adopting self-assessment (Hides, Davies, and Jackson 2004; Nenadál 2015), little empirical literature exists analysing the interrelationships between leadership dimensions and the factors that influence the decision to adopt excellence model in HEI. In particular, this study examines the leadership dimensions as determinants to adopt the EFQM model within Slovenian HE environment. 
The paper begins with a theoretical background regarding the quality initiatives in HEIs followed by a methodology section. Based on the studied literature, the research framework is proposed which is empirically validated by the survey results obtained among Slovenian HEIs. The empirical findings then demonstrate the interrelationships between leadership dimensions and provide insights regarding the influential factors of adopting the EFQM model in HEIS. The paper finishes with a discussion of the results and reaches a number of conclusions.

\section{Theoretical Background and Research Framework Development}

Based on extensive literature studies (e.g. Vakalopoulou, Tsiotras, and Gotzamani 2013; Cappelli et al. 2011) related to the quality initiative in public sector we have developed the research framework for investigating the interrelationships between leadership dimensions as shown in figure 1. In recent years, some scientific papers have paid attention to the relationships in the EFQM model (e.g. Calvo-Mora, Leal, and Roldan 2005; Gómez Gómez, Martínez Costa, and Martínez Lorente 2011; 2015). Previously, some other studies had analysed the relationships in the CAF model (e.g. Raharjo et al. 2015). Relying on findings demonstrated by these studies, this paper is focused on studying the relationships between leadership dimensions adopted from CAF model and their impact on the decision (noted as implementation enablers in the proposed research framework) to implement EFQM model in HEI. It can be emphasised that leaders in both the public and the private sectors have to develop their own vision, mission and values and are considered as role models of total quality excellence culture (Oakland 2011). Drawing on these arguments one could argue that leaders have the ability to create culture that stimulate employees' motivation and commitment towards quality and improvement initiatives (Calvo-Mora, Leal, and Roldan 2006). From this perspective, prior studies (Dahlgaard et al. 2013; Dahlgaard Park and Dahlgaard 2010) have pointed out the importance of building culture corporate culture and values in the path towards organizational excellence. Furthermore, based on mission and vision leaders need to establish quality policy and measurable objectives in order to successfully the implementation of the quality initiatives, such as quality management system, CAF or EFQM (Vakalopoulou, Tsiotras, and Gotzamani 2013; Tarí 2006).

Several prior studies (Davies, Hides, and Casey 2001; Hides, Davies, and Jackson 2004) have analysed how the business excellence models could serve as a framework for addressing the challenges faced by HEIS 
FIGURE 1

Research Framework

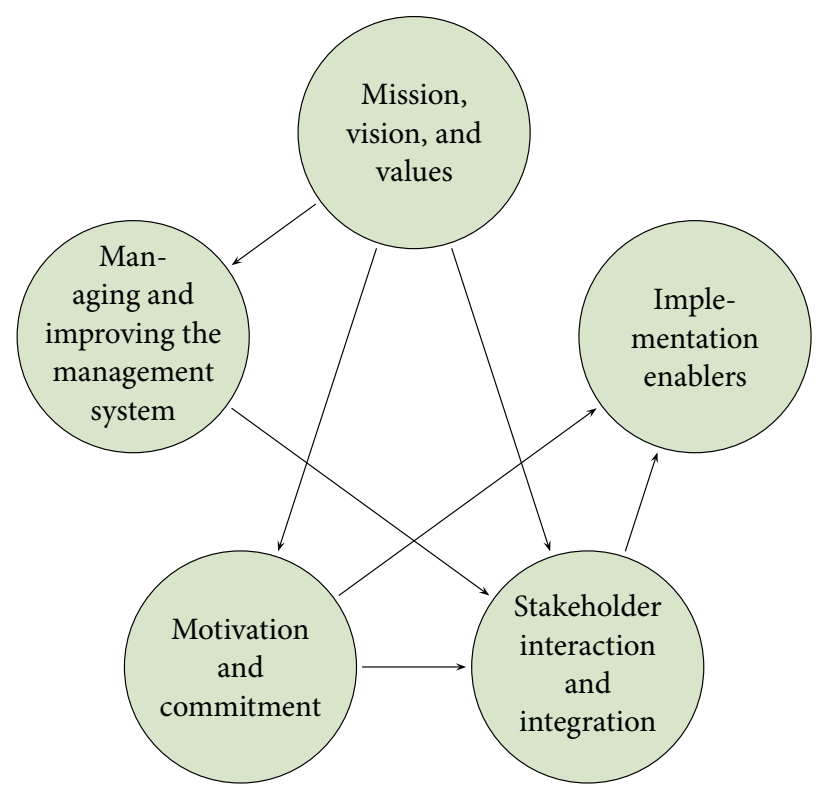

by the means of stakeholder pressure. As such, we argue that leadership through its efficient management system, through culture that create values, which in turn may shape the commitment of its employees, positively influence the stakeholder interaction and integration. Ultimately, this stakeholder focused strategy might have an important role in decisionmaking process to adopt and implement quality model, such as E FQM or CAF.

\section{Research Framework and Methodology}

\section{MEASURES}

In order to measure the key leadership dimensions, we took the Common Assessment Framework (C A F) 2013 and E FQM 2013 model as a reference. In this respect, the information included in the CAF and EFQM model is appropriate for developing measurement scales for the leadership dimension. Several topics were conceptualized to formulate the questionnaire, each tested on 7-point Likert scale. The Likert scale was based on the logic of the Plan - Do - Check - Act/Plan - Do - Check - Adjust (PDCA) system. In the subsequent empirical analysis 6-point scale was used, since the 7 corresponded to 'Prefer not to answer.' The following leadership dimensions were considered and validated in this study: mission, vision and values, managing and improving the management system, motivation 
and commitment, stakeholder interaction and integration. These dimensions are based upon the CAF 2013 sub-criterion, namely: Sub-criterion 1.1 Provide direction for the organisation by developing its mission, vision and values; Sub-criterion 1.2 Manage the organisation, its performance and its continuous improvement; Sub-criterion 1.3 Motivate and support people in the organisation and act as a role model; Sub-criterion 1.4 Manage effective relations with political authorities and other stakeholders. Apart from leadership dimensions, questionnaire consisted of the section (implementation enablers) which intended to capture the leadership dimensions by the means of the key success factors for the EFQM excellence model implementation. The last section of the questionnaire was devoted to general questions about respondents. The corresponding items for measuring the leadership dimensions are presented in table 5 .

\section{Sample and Data Collection}

This study is based on the use of internet-based survey methodology. Therefore, online questionnaire was used in order to collect the data. The survey was carried out among employees in the Slovenian public and private higher education sector. 45 Slovenian HE IS were considered for the purpose of this study. The HEIs were selected from the list of accredited HEIS that is available on the website of the directorate for Higher Education. In particular, the questionnaire was sent out to $3500 \mathrm{HE}$ teachers in the period from 4th March to 11th August 2014. Out of 3500 invited participants, 205 answered the questionnaire which yields a $5.86 \%$ response rate. The distribution of the respondents according to age shows a generally similar pattern for males and females ( $51.6 \%$ of males and $48.40 \%$ of females). Thirty-nine percent of respondents are in the 46-55 age group, followed by $20.64 \%$ of the respondents in the $26-35$ age group. The distribution of the respondents according to the obtained degree shows that $58.59 \%$ of the respondents obtained doctoral degree. Among all the respondents, $70.23 \%$ of the respondents declared that their employment is regular and full-time. Based on the position of the respondents, $20.0 \%$ of the respondents were full professors, 16.48 of the respondents were classified as scientific associates and $27.27 \%$ of the respondents were teaching assistants. The majority of the respondents (30.16\%) have between 26 and 35 years of working experience, followed by 23.02 of the respondents who have 6 to 15 years of working experience. The largest percentage of respondents (43.61) indicated that they are employed at the University of Ljubljana. 


\section{ANALYSIS METHOD}

In order to assess measurement model and structural model we utilized the Partial Least Squares Path Modeling (PLS-PM) using the R package plspm (Sanchez 2013). PLS-PM can be viewed from a broader conceptual perspective for analysing multiple relationships between blocks of variables. It is assumed that each block of variables plays the role of a theoretical concept represented in the form of a latent (unobserved) variable. A full path model is comprised by two sub-models: the structural model also known as inner model and the measurement model also known as outer model. The inner model is the part of the model that has to do with the relationships between latent variables. The outer model is the part of the model that has to do with the relationships between each latent variable and its block of indicators (Sanchez 2013). PLS-PM is a componentbased estimation method (Tenenhaus 2008). PLS-PM uses an iterative algorithm that separately solves out the blocks of the measurement model and then, in a second step, estimates the path coefficients in the structural model (Esposito Vinzi, Trinchera, and Amato 2010).

\section{Analysis and Results}

\section{MEASUREMENT MODEL ASSESSMENT}

In general, PLS Path Model is formed by two sub-models: the structural or inner model, and the measurement or outer model. The structural model is the part of the model that addresses the relationships between the latent variables. In contrast, the measurement model is the part of the model that addresses the relationships of a latent variable with its block of manifest variables (Sanchez 2013).

In order to assess the outer model one must examine the loadings and the communalities. The loadings are correlations between a latent variable and its indicators. In contrast, communalities are squared correlations and they measure the part of the variance between a latent variable and its indicator that is common to both (Sanchez 2013). According to the literature (Sanchez 2013) loadings greater than 0.7 are acceptable. Results regarding the outer model assessment are presented in table 5 . As can be seen from the table 5, the majority of indicators meet the threshold criterion of 0.7. There are few exceptions of values just below 0.7. Nevertheless, these indicators were also left in the model due to content considerations.

Besides checking the loadings of the indicators with their own latent variables, we must also check the cross-loadings that are available in the 
TABLE 1 Summary of the Results Regarding the Block Unidimensionality

\begin{tabular}{lrrrrr}
\hline Item & $(1)$ & $(2)$ & $(3)$ & $(4)$ & $(5)$ \\
\hline LV1 & $\mathrm{A}$ & 7 & 0.951 & 0.960 & 5.42 \\
LV2 & $\mathrm{A}$ & 10 & 0.937 & 0.946 & 6.39 \\
LV3 & $\mathrm{A}$ & 10 & 0.940 & 0.949 & 6.49 \\
LV4 & $\mathrm{A}$ & 10 & 0.895 & 0.914 & 5.16 \\
LV5 & $\mathrm{A}$ & 4 & 0.729 & 0.831 & 2.21 \\
\hline
\end{tabular}

Notes Column headings are as follows: (1) mode, (2) Mvs, (3) Cronbach's alpha, (4) Dillon-Goldstein's rho, (5) Eigenvalue. LV1 - mission, vision and values, LV 2 - managing and improving the management system, LV3 - motivation and commitment, LV 4 stakeholder interaction and integration, LV 5 - implementation enablers.

output of the plspm function. As such, we checked the cross-loadings matrix in order to identify any possible cross-loading.

Furthermore, the following indices were used to check unidimensionality: Cronbach's alpha, Dillon-Goldstein's rho and the first eigenvalue of the indicators' correlation matrix (table 1). The first column shows the type of measurement. In this case all the blocks are reflective. The Cronbach's alpha is a coefficient that is intended to evaluate how well a block of indicators measure their corresponding latent construct (Sanchez 2013). The alpha value for each block of indicators (i.e. latent variable) was well above the recommended value of 0.70 , which is considered satisfactory for empirical research (Sanchez 2013; Hair et al. 2010). According to the literature Dillon-Goldstein's rho index has some advantage over the Cronbach's alpha because it takes into account to which extent the latent variable explains its block of indicators. As a rule of thumb, a block is considered as unidimensional when the Dillon-Goldstein's rho is larger than 0.7 (Sanchez 2013). As shown in table 1, Dillon-Goldstein's rho values are well abo the recommended value of 0.7. The third metric includes an eigen-analysis of the correlation matrix of each set of indicators. If a block is unidimensional, then the first eigenvalue should be larger than one. It appears that eigenvalues for our blocks of interest are much larger than one.

\section{DESCRIPTIVE STATISTICS}

Prior to further statistical analysis, we first investigated the descriptive statistics for study variables. The descriptive statistics for leadership dimensions are presented in table 2. Observing the study variables, one can see that the highest mean value corresponds to the implementation enablers (4.04), while the lowest value corresponds to the mission, vision 
TABLE 2 Means, Standard Deviations and Correlations

\begin{tabular}{lrrrrrrr}
\hline Item & $M$ & SD & $(1)$ & $(2)$ & $(3)$ & $(4)$ & (5) \\
\hline (1) LV 1 & 3.26 & 1.683 & & & & & \\
(2) LV 2 & 3.31 & 1.563 & $0.906^{* *}$ & & & \\
(3) LV 3 & 3.39 & 1.681 & $0.846^{* *}$ & $0.878^{* *}$ & & & \\
(4) LV 4 & 3.42 & 1.521 & $0.742^{* *}$ & $0.777^{* *}$ & $0.821^{* *}$ & & \\
(5) LV 5 & 4.04 & 0.918 & $0.256^{* *}$ & $0.317^{* *}$ & $0.369^{* *}$ & $0.380^{* *}$ & - \\
\hline
\end{tabular}

NOTES ${ }^{* *}$ Correlation is significant at the o.o1 level (2-tailed).

and values (3.26). Moreover, the results indicate that the point estimate for the true mean of implementation enablers in the population is 4.04, and we are $95 \%$ confident that the true mean is between 3.86 and 4.21, while the true mean for mission, vision and values lies between 3.16 and 3.80 .

The results of the $t$-tests show that there is significant difference between mean values for the mission, vision and values (3.26) and the implementation enablers (4.04) $(t=-3.399, p=0.01)$, between managing and improving the management system (3.31) and implementation enablers (4.04) $(t=-4.278, p=0.00)$, between motivation and commitment (3.39) and implementation enablers (4.04) $(t=-3.785, p=0.00)$. The results also support significant difference between mean values for the stakeholder interaction and integration (3.42) and implementation enablers (4.04) $(t$ $=-4.820, p=0.00$ ).

Moreover, the bivariate Pearson correlation was used to measure the correlations among pairs of variables (leadership dimensions and implementation enablers). The results indicated positive relationships between included variables, with correlations ranging from 0.256 to $0.906(p<$ $0.01)$. For instance, mission, vision and values shows the strongest correlation with managing and improving the management system $(r=0.906$, $p<0.01)$. It appears that managing and improving the management system is strongly related to the motivation and commitment $(r=0.878, p$ $<0.01)$. Strong correlation was also found between mission, vision and values and motivation and commitment $(r=0.846, p<0.01)$ as well as between motivation and commitment and stakeholder interaction and integration $(r=0.821, p<0.01)$.

\section{STRUCTURAL MODEL ASSESSMENT}

The results regarding the assessment of the structural (inner) model are presented in table 3. One can inspect the $R^{2}$ that are the coefficients of de- 
TABLE 3 Summary of the Results Regarding the Inner Model Assessment

\begin{tabular}{llrrrr}
\hline Item & $(1)$ & $(2)$ & $(3)$ & $(4)$ & $(5)$ \\
\hline LV1 & Exogenous & 0.000 & 0.775 & 0.0000 & 0.775 \\
LV2 & Endogenous & 0.683 & 0.639 & 0.4365 & 0.639 \\
LV3 & Endogenous & 0.561 & 0.649 & 0.3639 & 0.649 \\
LV4 & Endogenous & 0.647 & 0.515 & 0.3330 & 0.515 \\
LV5 & Endogenous & 0.103 & 0.551 & 0.0566 & 0.551 \\
\hline
\end{tabular}

Notes Column headings are as follows: (1) type, (2) $R^{2}$, (3) block communality, (4) mean redundancy, (5) average variance extracted.

termination of the endogenous latent variables. The $R^{2}$ for 'Managing and improving the management system (LV2)' and 'Stakeholder interaction and integration (LV 4)' are above 0.6 which under the PLS-PM standards can be considered as high value (Sanchez 2013). According to the results, lower amount of variance (10.3\%) in the 'Implementation enablers (LV5)' is explained by its independent latent variables.

Furthermore, average communality indicates how much of the block variability is reproducible by the latent variable. It seems that the highest value in this respect achieved the latent variable 'Mission, vision and values (LV1), while the lowest value corresponds to the 'Stakeholder interaction and integration (LV4)'. Mean redundancy represents the percentage of the variance in the endogenous block that is predicted from the independent latent variables. High redundancy indicates ability to predict. For example, 'Mission, vision and values (LV1)' predicts $43.65 \%$ of the variability of 'Managing and improving the management system (LV2)' indicators.

AVE is the Average Variance Extracted which measures the amount of variance that a latent variable captures from its indicators in relation to the amount of variance due to measurement error (Sanchez 2013). As a rule of thumb, AVE greater than 0.50 is acceptable. According to the results, the AVE values for our inner model are above recommended value of 0.5 .

Furthermore, the results of the inner model, that is, the path coefficients are presented in table 4 and visualized in figure 2 . The path coefficients are calculated by ordinary least squares regressions between latent variables (Sanchez 2013). The direct effects are given by the path coefficients. The indirect effects are obtained as the product of the path coefficients by taking an indirect path. According to the results 'Mission, 
TABLE 4 Path Coefficients

\begin{tabular}{|c|c|c|c|c|c|c|c|}
\hline (1) & (2) & (3) & (4) & $(1)$ & (2) & (3) & (4) \\
\hline $\mathrm{LV}_{1} \rightarrow \mathrm{LV} 2$ & 0.8265 & 0.0000 & 0.8265 & $\mathrm{LV} 2 \rightarrow \mathrm{LV} 5$ & 0.0000 & 0.0719 & 0.0719 \\
\hline $\mathrm{LV} 1 \rightarrow \mathrm{LV} 3$ & 0.7487 & 0.0000 & 0.7487 & $\mathrm{LV}_{3} \rightarrow \mathrm{LV} 4$ & 0.5728 & 0.0000 & 0.5728 \\
\hline $\mathrm{LV} 1 \rightarrow \mathrm{LV} 4$ & 0.0268 & 0.6286 & 0.6554 & $\mathrm{LV}_{3} \rightarrow \mathrm{LV} 5$ & 0.0284 & 0.1705 & 0.1989 \\
\hline $\mathrm{LV} 1 \rightarrow \mathrm{LV} 5$ & 0.0000 & 0.2163 & 0.2163 & $\mathrm{LV}_{4} \rightarrow \mathrm{LV} 5$ & 0.2976 & 0.0000 & 0.2976 \\
\hline $\mathrm{LV} 2 \rightarrow \mathrm{LV} 4$ & 0.2417 & 0.0000 & 0.2417 & & & & \\
\hline
\end{tabular}

Notes Column headings are as follows: (1) relationships, (2) direct, (3) indirect, (4) total.

vision and values (LV1)' has a strong effect (0.8265) on 'Managing and improving the management system (LV2).' Mission, vision and values (LV1) also strongly effect (o.7487) the 'Motivation and commitment (LV3).' It appears that 'Motivation and commitment (LV3)' as well as 'Stakeholder interaction and integration (LV4)' influence the decision regarding the EFQM excellence model implementation in HEI, captured by the latent variable 'Implementation enablers (LV5)'.

Observing the indirect effect, one can see that 'Mission, vision and values (LV1)' indirectly through LV 2 and LV 3 effects the 'Stakeholder interaction and integration ( $(\mathrm{VV} 4)$ ) (calculated as $0.8265 \times 0.2417+0.7487 \times$ $0.5728=0.6286)$. Mission, vision and values (LV1) also indirectly effects (o.2163) the 'Implementation enablers (LV5).'

Overall, the findings suggest that 'Mission, vision and values (LV1)' is the most dominant among all the studied leadership dimensions. It significantly and directly relates to the three leadership dimensions.

\section{Discussion and Conclusions}

Recently, researchers have shown increasing interest in applying quality management models or excellence models in public sector (Raharjo et al. 2015). From this perspective, prior studies have investigated the applicability of these quality systems and models in higher education institutions (Mehralizadeh and Safaeemoghaddam 2010). This study, therefore, draws upon prior studies indicating that quality management practices, in particular the leadership practices, are at the core of an organization. Conceptually, leadership can be conceived as that combination of traits, values, attitudes, and behaviours that ultimately lead to the effective longterm performance of organizations (Lakshman 2006). This study is not solely focused on the issue of how to measure leadership excellence (Kanji 
FIGURE 2

Inner Model with Path Coefficients

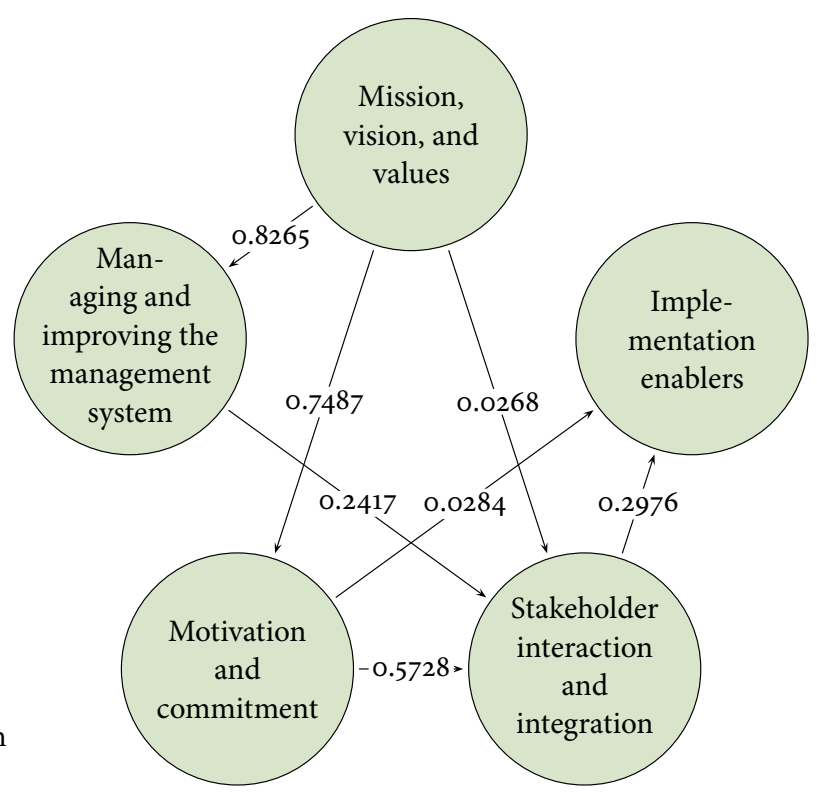

2008). Rather, the study explores how the dimensions of leadership criterion affect key success factors (i.e. implementation enablers) of the EFQM Excellence Model implementation in Slovenian higher education institutions. In this regard, this study contributes to the prior studies suggesting that the leadership criterion is one of the main contributor to the business excellence models (Karimi et al. 2013; Calvo-Mora, Leal, and Roldan 2005).

PLS-PM analysis was used to arrive at these conclusions, which seemed to be quite compelling. We have tested and found support for the interpretation that leadership dimensions positively impact the implementation enablers. In particular, results of the PLS-PM model suggest that the leadership dimension 'Mission, vision and values (LV1)' positively and directly influence three dimensions of leadership, namely: 'Managing and improving the management system (LV2),' 'Motivation and commitment (LV3)' and 'Stakeholder interaction and integration (LV4).' Therefore, it could be suggested that within higher education institutions where leadership is recognized as an important determinant of the EFQM excellence model implementation, there is stronger focus of their leaders to build proper quality culture, to develop management system as well as to integrate diverse range of stakeholders in their decisions. These findings provide further confirmation of previous studies (Kern 
Pipan, Gomišček, and Kljajić 2014; Dahlgaard et al. 2013; Gómez Gómez, Martínez Costa, and Martínez Lorente 2011) that have emphasised the importance of management commitment, organizational culture, team work, values and communication in the successful introduction of $\mathrm{TQM}$ and business excellence models (BEMs) in the organizations. As suggested by Anyaleme (2007), the maintenance and improvement of the quality of higher education institutions must be the responsibility and full commitment of institutional leadership. Although our study is primarily focused on the leadership criterion, it should be noted that prior studies highlighted the inconsistency between leadership intention and the practices (Dahlgaard et al. 2013). Authors suggested that the culture aspect in terms of value, vision and mission building is explicitly focused under the leadership criterion, while this focus is more or less ignored in other enablers, such as strategy, partnership \& resources as well as in the process criterion.

Likewise, our results provided evidence to support that 'Stakeholder interaction and integration (LV4)' positively and significantly effects the 'Implementation enablers (LV5).' It is argued that stakeholders' involvement is crucial for successful implementation of the EFQM Excellence Model. Accordingly, policy and strategy must be based on the needs and the expectations of key stakeholders of an organization (Calvo-Mora, Leal, and Roldan 2006). Successful implementation of the EFQM Excellence Model is not dependent just on stakeholder interaction and integration. Drawing on Davies (2008) one can conclude that EFQM Excellence Model should be integrated into the strategic planning systems of the organization as well as into other aspects of the organization. Moreover, Jackson (2001) argues that every effort must be made to actively involve all employees as fully as possible in continuous improvement activities. Furthermore, it is argued that internal evaluation process within HEI is potentially valuable, especially if this process becomes an integral part of each department and is performed on a continuous basis (Mehralizadeh et al. 2007).

Drawing on the results of the study, one can highlight several recommendations for the improvement of the leadership in Slovenian HE as well as the recommendations for the improvement of the different circumstances that are perceived as prerequisite for the implementation of the EFQM excellence model in Slovenian HE environment. Fundamental changes that are required for the successful implementation of the EFQM excellence model in Slovenian HE can be divided into several ar- 
eas. It is argued that leadership is an essential element for the successful integration of the quality principles into the HE. Moreover, leadership is the important element for the transition from the existing quality systems to EFQM excellence model in Slovenian HE (Pungeršek et al. 2015). Leadership can be further classified into the following categories: public leadership and governance and leadership within HEI. Leadership in HEI is especially important in the context of achieving desired quality in all levels of the HEI. As suggested by the Dean and Bowen (1994), the management's commitment and leadership in quality must be visible, permanent and present on all management levels, since it acts as the guide and promoter of the total quality management implementation process. Furthermore, employees are also considered as an important element of the successful implementation of the EFQM excellence model in HEI. One can argue that EFQM excellence model should be in accordance with other organizational systems as well as its implementation and deployment should be based on full and active involvement of all employees (Davies 2008).

Political authorities and other key stakeholder should also be outlined when discussing the possibilities of improving the quality in $\mathrm{HE}$. Ultimately, quality in $\mathrm{HE}$ is essentially a socio-cultural and political issue with underlying economical, technological and social implications (Mehralizadeh 2005; Stensaker 2007).

Furthermore, within the Slovenian $\mathrm{HE}$ environment it is essential to recognize the requirements of the Slovenian Quality Assurance Agency for Higher Education, since these can also influence the decision of whether the EFQM excellence model is suitable for the Slovenian $\mathrm{HE}$. Indeed, as has been elaborated in prior studies (Prašnikar and Kern-Pipan 2011) this model can be successfully used as a tool to manage changes and improve the quality of HEIs. Likewise, Zeps, Iljins, and Ribickis (2017) suggest that integration of EFQM excellence model and Standards and Guidelines for Quality Assurance in the European Higher Education Area (ESG) into university strategy is considered as beneficial for further development of university.

As with all empirical studies, there are a number of limitations and directions for future research. We acknowledge that there are possible sources of bias concerning the sample distribution. As such, one boundary condition for our study pertains to the generalizability of our findings beyond the population from which our sample respondents are drawn. Accordingly, future studies could increase the generalisability of the re- 
TA B LE 5 Questionnaire Items and Outer Model Assessment Statistics

\begin{tabular}{|c|c|c|c|c|}
\hline Mission, vision and values & (1) & (2) & (3) & (4) \\
\hline $\begin{array}{l}\text { Leaders develop the mission and vision of HEI by involv- } \\
\text { ing employees and other key stakeholders. }\end{array}$ & 0.178 & 0.927 & 0.860 & 0.0000 \\
\hline $\begin{array}{l}\text { Leaders shape values in accordance with the mission and } \\
\text { vision of HEI and respect general framework of values in } \\
\text { public sector. }\end{array}$ & 0.167 & 0.910 & 0.828 & 0.0000 \\
\hline $\begin{array}{l}\text { Leaders ensure that mission, vision, values, strategic and } \\
\text { operative goals are articulated to the employees and other } \\
\text { key stakeholders. }\end{array}$ & 0.160 & 0.878 & 0.770 & 0.0000 \\
\hline $\begin{array}{l}\text { Leaders regularly review mission, vision, and values in } \\
\text { accordance with the changes in external environment } \\
\text { (e.g. economic change, political change, socio cultural } \\
\text { change). }\end{array}$ & 0.161 & 0.862 & 0.742 & 0.0000 \\
\hline $\begin{array}{l}\text { Leaders develop management system which prevents } \\
\text { the unethical behaviour and simultaneously supports } \\
\text { employees at solving the ethical dilemmas. }\end{array}$ & 0.158 & 0.869 & 0.755 & 0.0000 \\
\hline $\begin{array}{l}\text { Leaders manage the prevention of corruption by iden- } \\
\text { tifying the potential areas of conflicts of interest and } \\
\text { establishing guidelines for employees. }\end{array}$ & 0.143 & 0.840 & 0.705 & 0.0000 \\
\hline $\begin{array}{l}\text { Leaders strengthen mutual trust, loyalty and respect } \\
\text { among themselves and employees and regularly evaluate } \\
\text { and propose the standards of good leadership. }\end{array}$ & 0.166 & 0.873 & 0.761 & 0.0000 \\
\hline
\end{tabular}

Continued on the next page

sults by taking caution in controlling for possible extraneous variation. Several control variables could be used for this purpose, such as institution's size, governance structure and many other contextual factors. One research opportunity is to examine the factors (i.e. antecedents) that drive or hinder the business excellence framework deployment.

One of the limitations of this study is low response rate (5.86\%). Although low response rate is one of the major limitations of web-based surveys in general (Eysenbach 2005), it still reflects the unwillingness of potential respondents to express their point of view regarding the studied topic. In this regard, one can conclude that general attitude in Slovenian $\mathrm{HE}$ might hinder the implementation of the crucial changes concerning the improvement of the quality of HEIS and ultimately the image of the institutions. From this perspective, future studies could use several contextual variables to better explain the quality movement phenomenon in Slovenian HE. 
TABLE 5 Continued from the previous page

\begin{tabular}{|c|c|c|c|c|}
\hline Managing and improving the management system & (1) & (2) & (3) & (4) \\
\hline $\begin{array}{l}\text { Leaders define the appropriate forms of governance (lev- } \\
\text { els, responsibility, and accountability) and enable process } \\
\text { management system in compliance with the strategy and } \\
\text { stakeholders' demands. }\end{array}$ & 0.134 & 0.842 & 0.709 & 0.4843 \\
\hline $\begin{array}{l}\text { Leaders recognize and prioritize actions regarding the } \\
\text { change in structure, operations and management of HEI. }\end{array}$ & 0.136 & 0.823 & 0.678 & 0.4630 \\
\hline $\begin{array}{l}\text { Leaders establish measurable targets - specific objectives } \\
\text { concerning the outcomes in all levels of HEI. }\end{array}$ & 0.125 & 0.810 & 0.656 & 0.4479 \\
\hline $\begin{array}{l}\text { Leaders develop information management system, with } \\
\text { the inputs emerging from the risk management and inter- } \\
\text { nal control system and continuously monitor the achieve- } \\
\text { ment of the HEI objectives (e.g. by using the balanced } \\
\text { scorecard - BSC). }\end{array}$ & 0.125 & 0.769 & 0.592 & 0.4042 \\
\hline $\begin{array}{l}\text { Leaders deploy the principles of total quality manage- } \\
\text { ment principles and implement the quality management } \\
\text { system/model (e.g. CAF, EFQM, ISO 9001). }\end{array}$ & 0.116 & 0.745 & 0.556 & 0.3797 \\
\hline $\begin{array}{l}\text { Leaders develop and adapt the strategy of e-education } \\
\text { with the strategic and performance goals of HEI. }\end{array}$ & 0.101 & 0.742 & 0.550 & 0.3758 \\
\hline $\begin{array}{l}\text { Leaders create proper factors/frameworks for managing } \\
\text { of processes, project management and teamwork. }\end{array}$ & 0.122 & 0.804 & 0.647 & 0.4419 \\
\hline $\begin{array}{l}\text { Leaders create the conditions for effective communica- } \\
\text { tion inside and outside the HEI based on the recognition } \\
\text { of communication as one of the most important key suc- } \\
\text { cess factors of HEI. }\end{array}$ & 0.121 & 0.829 & 0.688 & 0.4698 \\
\hline $\begin{array}{l}\text { Leaders show the commitment to continuous improve- } \\
\text { ment of HEI and commitment to build innovation cul- } \\
\text { ture by actively engaging the employees. }\end{array}$ & 0.139 & 0.831 & 0.690 & 0.4715 \\
\hline $\begin{array}{l}\text { Leaders communicate the reasons for change programs } \\
\text { and effects of these changes on employees and key stake- } \\
\text { holders. }\end{array}$ & 0.130 & 0.791 & 0.625 & 0.4269 \\
\hline
\end{tabular}

Continued on the next page

Apart from leadership dimension, future studies could be focused on investigation of other EFQM enabler criteria in $\mathrm{HE}$. For instance, future studies could focus on searching the possible mediation mechanisms in the relation between leadership criterion and results.

In addition, our results have also significant managerial implications. Accordingly, practical implications that arise from this study emphasise the need for institutional leaders to manage and balance the leadership 
TAB LE 5 Continued from the previous page

\begin{tabular}{|c|c|c|c|c|}
\hline Moti & (1) & (2) & (3) & (4) \\
\hline $\begin{array}{l}\text { Leaders lead by an example; therefore, as a role model } \\
\text { and in accordance with established goals and values. }\end{array}$ & 0.131 & 0.815 & 0.664 & 0.3720 \\
\hline $\begin{array}{l}\text { Leaders encourage the culture of mutual trust and respect } \\
\text { among employees based on actions that discourage any } \\
\text { forms of discrimination. }\end{array}$ & 0.121 & 0.795 & 0.632 & 0.354 \\
\hline $\begin{array}{l}\text { Lead } \\
\text { regar }\end{array}$ & 0.122 & 0.799 & 0.638 & 0.3579 \\
\hline $\begin{array}{l}\text { Leaders support the employees, so that they effectively } \\
\text { perform their tasks, plans and achieve the common goals } \\
\text { of HEI. }\end{array}$ & 0.125 & 0.796 & 0.634 & 0.355 \\
\hline $\begin{array}{l}\text { Leaders provide feedback to employees in order to im- } \\
\text { prove the performance of teams and individual employ- } \\
\text { ees. }\end{array}$ & 0.128 & 0.840 & 0.706 & 0.3957 \\
\hline $\begin{array}{l}\text { Leaders stimulate, encourage and empower employees } \\
\text { with delegating the authority, responsibilities and ac- } \\
\text { countability. }\end{array}$ & 0.118 & 0.814 & 0.663 & 0.3717 \\
\hline ulate & 0.126 & 0.814 & 0.663 & 0.3716 \\
\hline $\begin{array}{l}\text { Leaders express personal readiness to accept recommen- } \\
\text { dations/proposals from employees, responding construc- } \\
\text { tively to feedback. }\end{array}$ & 0.131 & 0.835 & 0.698 & 0.391 \\
\hline gnitions and aw & 0.122 & 0.784 & 0.614 & 0.344 \\
\hline e specific needs and pri- & 0.116 & 0.761 & 0.579 & 0.324 \\
\hline $\begin{array}{l}\text { Leaders at } \\
\text { needs and }\end{array}$ & 0.164 & 0.761 & 0.579 & 0.374 \\
\hline
\end{tabular}

Continued on the next page

dimensions in a way that this successfully facilitates implementation as well as sustained use of the EFQM Excellence Model. Seen in this way, for the implementation of any quality improvement initiative, it is necessary to have the commitment from the HEI management. Management commitment to quality should be reflected through a well-defined policy and strategy, implemented and communicated on all levels of the HE I. By engaging stakeholders in quality improvement initiatives, one can ensure that the initiatives are implemented effectively, achieve intended outcomes, and contribute to sustainable changes in the quality of the 
TABLE 5 Continued from the previous page

\begin{tabular}{|c|c|c|c|c|}
\hline Stakeholder interaction and integration & (1) & (2) & (3) & (4) \\
\hline $\begin{array}{l}\text { Leaders give support to political authorities during the } \\
\text { development of public policies related to HEI. }\end{array}$ & 0.128 & 0.761 & 0.580 & 0.3751 \\
\hline $\begin{array}{l}\text { Leaders recognize and integrate public policies that are } \\
\text { important to HEI. }\end{array}$ & 0.118 & 0.713 & 0.509 & 0.3293 \\
\hline $\begin{array}{l}\text { Leaders assure that the goals of } \mathrm{HEI} \text { are in accordance } \\
\text { with the results and impact of public policies and political } \\
\text { decisions and make agreements with policy authorities } \\
\text { regarding the required resources. }\end{array}$ & 0.146 & 0.774 & 0.599 & 0.3874 \\
\hline $\begin{array}{l}\text { Leaders integrate political authorities and other stake- } \\
\text { holders into the development of the governance system of } \\
\text { HEI. }\end{array}$ & 0.117 & 0.639 & 0.408 & 0.2641 \\
\hline $\begin{array}{l}\text { Leaders maintain regular and proactive relations with } \\
\text { political authorities on the respective executive and legis- } \\
\text { lation areas. }\end{array}$ & 0.122 & 0.682 & 0.466 & 0.3014 \\
\hline $\begin{array}{l}\text { Leaders develop and maintain partnerships and networks } \\
\text { with the relevant stakeholders (e.g. students, local com- } \\
\text { munity, and professional associations). }\end{array}$ & 0.152 & 0.774 & 0.599 & 0.3878 \\
\hline $\begin{array}{l}\text { Leaders participate in the activities of professional as- } \\
\text { sociations, representational organizations and other key } \\
\text { interest groups. }\end{array}$ & 0.154 & 0.709 & 0.502 & 0.3251 \\
\hline $\begin{array}{l}\text { Leaders build and enhance public awareness, image and } \\
\text { recognition of HEI and its services. }\end{array}$ & 0.134 & 0.656 & 0.430 & 0.2781 \\
\hline $\begin{array}{l}\text { Leaders develop service oriented mark } \\
\text { which is focused on the stakeholders } r\end{array}$ & 0.157 & 0.689 & 0.475 & 0.3071 \\
\hline $\begin{array}{l}\text { Engagement of the leaders in the field of managing the } \\
\text { organization based on the development of its mission, } \\
\text { vision and values is the key success factor of the EFQM } \\
\text { excellence model implementation in HEI. }\end{array}$ & 0.371 & 0.797 & 0.635 & 0.0652 \\
\hline
\end{tabular}

Continued on the next page

HE. Nonetheless, proper measures (key performance indicators) should be established in order to monitor the progress towards achieving HEI goals.

\section{References}

Anyaleme, S. C. 2007. 'Applying Leadership Criterion of the European Excellence model for achieving Quality Mangagement in Higher Education Institutions.' Academic Leadership Journal 5 (2): 12-26.

Brennan, J. L., and T. Shan. 2000. Managing Quality in Higher Education: 
TAB LE 5 Continued from the previous page

\begin{tabular}{|c|c|c|c|c|}
\hline Implementation enablers & (1) & (2) & (3) & (4) \\
\hline $\begin{array}{l}\text { Engagement of the leaders in the field of managing the } \\
\text { organization based on its performance and continuous } \\
\text { improvement is the key success factor of the EFQM excel- } \\
\text { lence model implementation in HEI. }\end{array}$ & 0.393 & 0.797 & 0.635 & 0.0653 \\
\hline $\begin{array}{l}\text { Engagement of the leaders in the field of motivation and } \\
\text { support of the employees as well as acting as a role model } \\
\text { is the key success factor of the EFQM excellence model } \\
\text { implementation in HEI. }\end{array}$ & 0.317 & 0.701 & 0.491 & 0.0504 \\
\hline $\begin{array}{l}\text { Engagement of the leaders in the field of managing the } \\
\text { relationships with political authorities and other stake- } \\
\text { holders is the key success factor of the EFQM excellence } \\
\text { model implementation in HEI. }\end{array}$ & 0.254 & 0.665 & 0.442 & 0.0454 \\
\hline
\end{tabular}

Notes Column headings are as follows: (1) weight, (2) loading, (3) communality, (4) redundancy.

An International Perspective on Institutional Assessment and Change. Buckingham: Open University Press.

Calvo-Mora, A., A. Leal, and J. L. Roldan 2005. 'Relationships between the EFQM Model Criteria: A Study in Spanish Universities.' Total Quality Management \& Business Excellence 16 (6): 741-70.

Calvo-Mora, A., A. Leal, and J. L. Roldan. 2006. 'Using Enablers of the E F Q M Model to Manage Institutions of Higher Education.' Quality Assurance in Education 14 (2): 99-122.

Cappelli, L., R. Guglielmetti, G. Mattia, R. Merli, and M. F. Renzi 2011. 'Peer Evaluation to Develop Benchmarking in the Public Sector.' Benchmarking: An International Journal 18 (4): 490-509.

Dahlgaard, J. J., C. K. Chen, J. Y. Jang, L. A. Banegas, and S. M. Dahlgaard Park. 2013. 'Business Excellence Models: Limitations, Reflections and Further Development.' Total Quality Management \& Business Excellence 25 (5-6): 519-38.

Dahlgaard Park, S. M. (2011). 'The Quality Movement: Where Are You Going?' Total Quality Management \& Business Excellence 22 (5): 493-516.

Dahlgaard Park, S. M., and J. J. Dahlgaard. 2010. 'Organizational Learnability and Innovability.' International Journal of Quality and Service Sciences 2 (2): 153-74.

Davies, J. (2008). 'Integration: Is It the Key to Effective Implementation of the EFQM Excellence Model?' International Journal of Quality \& Reliability Management 25 (4): 383-99.

Davies, J., M. T. Hides, and S. Casey. 2001. 'Leadership in Higher Education.' Total Quality Management 12 (7 \& 8): 1025-30. 
Dean, J. W., and D. E. Bowen. 1994. 'Management Theory and Total Quality: Improving Research and Practice through Theory Development.' Academy of Management Review 19 (3): 392-418.

Eskildsen, J. K., and J. J. Dahlgaard. 20oo. 'A Causal Model for Employee Satisfaction.' Total Quality Management 11 (8): 1081-94.

Esposito Vinzi, V., L. Trinchera, and S. Amato. 2010. 'Pls Path Modeling: From Foundations to Recent Developments and Open Issues for Model Assessment and Improvement.' In Handbook of Partial Least Squares: Concepts, Methods, and Applications, Computational Statistics, vol. 2, edited by V. E. Vinzi, W. W. Chin, J. Henseler, and H. Wang, 47-82. Heidelberg: Springer.

Eysenbach, G. 2005. 'Using the Internet for Surveys and Research.' In Evaluating the Organizational Impact of Healthcare Information Systems, edited by J. G. Anderson and C. E. Aydin, 129-43. New York: Springer.

Flumerfelt, S., and M. Banachowski. 2011. 'Understanding Leadership Paradigms for Improvement in Higher Education.' Quality Assurance in Education 19 (3): 224-47.

Gómez Gómez, J., M. Martínez Costa, and A. R. Martínez Lorente. 2011. 'A Critical Evaluation of the E F Q Model.' International Journal of Quality \& Reliability Management 28 (5): 484-502.

Gómez Gómez, J., M. Martínez Costa, and A. R. Martínez Lorente 2015. 'An In-Depth Review of the Internal Relationships of the EFQM Model.' The TQM Journal 27 (5): 486-502.

Hair, J. F. Jr., W. C. Black, B. J. Babin, and R. E. Anderson. 2010. Multivariate Data Analysis. 7 th ed. London: Pearson Prentice Hall.

Hallinger, P., and R. H. Heck 1996. 'Reassessing the Principal's Role in School Effectiveness: A Review of Empirical Research, 1980-1995.' Educational Administration Quarterly 32 (1): 5-44.

Hides, M. T., J. Davies, and S. Jackson. 2004. 'Implementation of E FQM Excellence Model Self-Assessment in the u K Higher Education Sector - Lesson Learned from Other Sectors.' The TQM Magazine 16 (3): 194201.

Idris, M. A., and M. Zairi. 2006. 'Sustaining TQM: A Synthesis of Literature and Proposed Research Framework.' Total Quality Management \& Business Excellence 17 (9): 1245-60.

Jackson, S. 2001. 'Successfully Implementing Total Quality Management Tools within Healthcare: What Are the Key Actions?' International Journal of Health Care Quality Assurance 14 (4): 157-63.

Kanji, G. K. 2008. 'Leadership Is Prime: How Do You Measure Leadership Excellence?' Total Quality Management \& Business Excellence 19 (4): 417-27.

Karimi, A., H. Safari, S. H. Hashemi, and P. Kalantar. 2013. 'A Study of the 
Baldrige Award Framework Using the Applicant Scoring Data.' Total Quality Management \& Business Excellence 25 (5-6): 1-17.

Kaynak, H. 2003. 'The Relationship between Total Quality Management Practices and Their Effects on Firm Performance.' Journal of Operations Management 21 (4): 405-35.

Kern Pipan, K., B. Gomišček, and M. Kljajić. 2014. 'Slovenian National Excellence Award and Total Quality Management Deployment in Slovenian Companies.' Total Quality Management \& Business Excellence 25 (7-8): 750-62.

Lakshman, C. 2006. 'A Theory of Leadership for Quality: Lessons from TQM for Leadership Theory.' Total Quality Management \& Business Excellence 17 (1): 41-6o.

Leithwood, K., B. Mascall, T. Strauss, R. Sacks, N. Memon, and A. Yashkina. 2007. 'Distributing Leadership to Make Schools Smarter: Taking the Ego Out of the System.' Leadership and Policy in Schools 6 (1): 37-69.

Mehralizadeh, Y. 2005. 'New Reforms in the Management of the University'. Higher Education Policy 18 (1): 67-82.

Mehralizadeh, Y., and M. Safaeemoghaddam 2010. 'The Applicability of Quality Management Systems and Models to Higher Education.' The TQM Journal 22 (2): 175-87.

Mehralizadeh, Y., M. J. Pakseresht, M. Baradaran, and S. Shahi. 2007. 'The Dilemma of Internal Evaluation in Higher Education: A Longitudinal Case Study. Quality Assurance in Education 15 (3): 352-68.

Murgatroyd, S., and C. Morgan. 1993. Total Quality Management and the School. Buchingham: Open University Press.

Nenadál, J. 2015. 'Comprehensive Quality Assessment of Czech Higher Education Institutions.' International Journal of Quality and Service Sciences 7 (2-3): 138-51.

Oakland, J. 2011. 'Leadership and Policy Deployment: The Backbone of TQM.' Total Quality Management \& Business Excellence 22 (5): 517-34.

Osseo-Asare, A. E., D. Longbottom, and W. D. Murphy. 2005. 'Leadership Best Practices for Sustaining Quality in u K Higher Education from the Perspective of the EFQM Excellence Model.' Quality Assurance in Education 13 (2): 148-70.

Prašnikar, A., and K. Kern-Pipan. 2011. 'Pristopi za spodbujanje kakovosti in odličnosti poslovanja v visokem šolstvu.' In 30. International Conference on Organizational Science Development, edited by M. Ferjan, M. Kljajić-Borštnar, and A. Pucihar, 1101-09. Kranj: Moderna organizacija.

Pungeršek, M., M. Maletič, J. Suklan, and M. Meško. 2015. 'Voditeljstvo in uvajanje modela odličnosti EFQM v slovenskem visokem šolstvu.' Revija za univerzalno odličnost 4 (4): 155-70. 
Raharjo, H., R. Guglielmetti Mugion, H. Eriksson, I. Gremyr, L. Di Pietro, and M. F. Renzi, 2015. 'Excellence Models in the Public Sector: Relationships between Enablers and Results.' International Journal of Quality and Service Sciences 7 (1): 120-35.

Rao Tummala, V. M., and C. L. Tang. 1996. 'Strategic Quality Management, Malcolm Baldrige and European Quality Awards and Iso 9000 Certification: Core Concepts and Comparative Analysis.' International Journal of Quality \& Reliability Management 13 (4): 8-38.

Sanchez, G. 2013. PLS Path Modeling with R. Berkeley, cA: Trowchez.

Sentočnik, S. 2012. 'Distributed Leadership as a Form of Work Redesign: Exploring its Development and Implementation in High Schools in Slovenia.' PhD dissertation, University of Ljubljana.

Sila, I. 2007. 'Examining the Effects of Contextual Factors on TQM and Performance through the Lens of Organizational Theories: An Empirical Study.' Journal of Operations Management 25 (1): 83-109.

Spillane, J. P., and E. Camburn. 2006. The Practice of Leading and Managing: The Distribution of Responsibility for Leadership and Management in Schoolhouse. San Francisco, CA: American Educational Research Association.

Srikanthan, G., and J. Dalrymple 2004. 'A Synthesis of a Quality Management Model for Education in Universities.' International Journal of Educational Management 18 (4): 266-79.

Stensaker, B. 2007. 'Quality as Fashion: Exploring the Translation of a Management Idea into Higher Education.' In Quality Assurance in Higher Education: Trends in Regulation, Translation and Transformation, edited by F. Westerheijden, B. Stensaker, and M. J. Pires da Rosa, 99-118. Berlin: Springer.

Tarí, J. J. 2006. 'An EFQm Model Self-Assessment Exercise at a Spanish University.' Journal of Educational Administration 44 (2): 170-88.

Tenenhaus, M. 2008. 'Component-Based Structural Equation Modelling.' Total Quality Management \& Business Excellence 19 (7-8): 871-86.

Vakalopoulou, M. A., G. Tsiotras, and K. Gotzamani. 2013. 'Implementing CA F in Public Administration.' Benchmarking: An International Journal 20 (6): 744-64.

Wiklund, H., B. Klefsjö, P. S. Wiklund, and B. Edvardsson. 2003. 'Innovation and TQM in Swedish Higher Education Institutions Possibilities and Pittfalls.' The TQM Magazine 15 (2): 99-107.

Zeps, A., J. Iljins, and L. Ribickis. 2017. 'Integration of EFQM Excellence Model in RTU Development Strategy: Pilot Project Review.' In Proceedings of the 5th International Scientific Conference 'Contemporary Issues in Business, Management and Education,' 366-75. Vilnius: Vilnius Gediminas Technical University. 